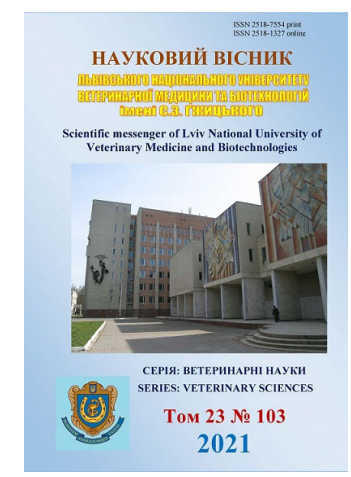

\author{
Науковий вісник Дьвівського національного університету \\ ветеринарної медицини та біотехнологій імені С.3. Гжицького. \\ Серія: Ветеринарні науки \\ Scientific Messenger of Lviv National University \\ of Veterinary Medicine and Biotechnologies. \\ Series: Veterinary sciences
}

UDC 636.5.09:614.31:340.66

\title{
Specific peculiarity of the forensic veterinary expert conclusion structure according to the research of fowl corpse results
}

\author{
I. V. Yatsenko, R. H. Kazantsev \\ State Biotechnological University, Kharkiv, Ukraine
}

Article info

Received 07.07.2021

Received in revised form 09.08 .2021

Accepted 10.08.2021

State Biotechnological University, Mala Danilivka,

Dergachi district, Kharkiv region, 62341, Ukraine.

Tel.: +38-067-186-06-65

E-mail:yacenko-1971@ukr.net
Yatsenko, I. V., \& Kazantsev, R. H. (2021). Specific peculiarity of the forensic veterinary expert conclusion structure according to the research of fowl corpse results. Scientific Messenger of Lviv National University of Veterinary Medicine and Biotechnologies. Series: Veterinary sciences, 23(103), 60-77. doi: 10.32718/nvlvet10310

The article identifies and systematizes some issues of the forensic veterinary expert conclusion structure according to the research of fowl carcass results. It is claimed that the sequence of fowl carcass examination results presentation is determined by a forensic veterinary expert with account the examination specifics, the object study state and the issues nature raised by the subject of examination appointment for the expert decision. It is shown that the peculiarity of its introductory part is a specific issues list raised for the forensic veterinary expert decision by the research subject. Mandatory elements of the "Research" section in the expert's conclusion is a statement of the individual documents study results in the proceedings and directly related to the examination (extract from the animal's health history, fowl ambulatory card, site inspection report, etc.), carcass registration data, results of its external and internal research according to certain algorithms description, results of additional researches (forensic chemical, histological, forensic toxicological, etc.), forensic veterinary diagnosis and the synthesizing part conclusion formulation. The final part of the expert's conclusion is the questions answer to the mentioned in the introductory part in a categorical or, as an exception, in a probable form. Be sure to indicate the damage nature or pathological changes, their location, the cause of fowl death, the causal relationship between the damage caused to the fowl health and the onset of its death. The appendices peculiarity is that they are drawn up in the photo tables form, which carry information about the fowl carcasses forensic veterinary examination stages, supplement and confirm the expert's opinion verbal part.

Key words: forensic veterinary examination, fowl corpse, forensic expert conclusion, structure.

\section{Особливості структури висновку судово-ветеринарного експерта результатами дослідження трупа птиці}

\author{
I. В. Яценко, Р. Г. Казанцев
}

Державний біотехнологічний університет, м. Харків, Украӥна

В роботі означено і систематизовано деякі питання структури висновку судово-ветеринарного експерта за результатами дослідження трупа птиці. Стверджується, щзо послідовність викладу результатів дослідження трупа птиці визначається судово-ветеринарним експертом, враховуючи особливості проведення експертизи, стану об 'єкта дослідження і характеру питань, поставлених суб'єктом призначення експертизи на вирішення експерта. Показано, щзо особливістю його вступної частини є специфічний перелік питань, поставлених на вирішення судово-ветеринарному експерту суб'єктом призначення експертизи. Обов 'язковими елементами розділу “Дослідження” у висновку експерта є виклад результатів дослідження окремих документів, що $\epsilon$ в матеріалах провадження $і$ безпосередньо стосуються експертизи (виписка з історії хвороби тварини, амбулаторна карта птиці, протокол огляду місия події тощч), реєстраційні дані трупа, описання результатів його зовнішнього та внутрішнього дослідження за визначеними алгоритмами, результати додаткових досліджень (судово-хімічні, гістологічні, судово-токсикологічні тощо), формулювання судово-ветеринарного діагнозу та складання синтезуючої частини висновку. Заключна частина висновку 
експерта є відповіддю на питання, зазначені у вступній частині в категоричній або, як виняток, у ймовірній формі. Обов'язково зазначають характер ушкоджень чи виявлених патологічних змін, їхню локалізацію, причину смерті птиці, причинно-наслідковий зв 'язок між шкодою, заподіяною здоров'ю птиці й настанням ї̈ смерті. Особливістю додатків є те, ше їх оформляють у вигляді фототаблиць, котрі несуть інформацію про етапи судово-ветеринарного дослідження трупа птиці, доповнюють $i$ підтверджують вербальну частину висновку експерта.

Ключові слова: судово-ветеринарна експертиза, труп птиці, укладання висновку судового експерта, структура.

\section{Вступ}

Одним із об'єктів судово-ветеринарної експертизи $\epsilon$ птиця, незалежно від: належності (приватна, державна, комунальна), умов мешкання (в неволі, природних ареалах), продуктивності (продуктивна, непродуктивна), місця утримання (в домашніх умовах, в умовах агрофірм, природних ареалів, зоопарків, цирків, зоологічних куточків тощо), цілей використання (в кінематографічних, спортивних, видовищних заходах, виставках, експериментальних, наукових і навчальних цілях), віку (молода, зріла, стара), статі (самці, самки), під час відтворення й розведення, утримання, годівлі, використання, полювання, видовищних заходів, перевезення, підготовки до первинної переробки на бійнях чи інших птахопереробних підприємствах, проведення лабораторних досліджень, лікування, евтаназії, стану (порадний, безпорадний), а отже посідає провідне місце в структурі експертних досліджень (Cooper \& Cooper, 1991; Wobeser, 1996; Forbes, 1998; Zon \& Ivanovska, 2014; Viner et al., 2016; Russell \& Franson, 2014; Yatsenko et al., 2018; Yatsenko et al., 2020).

Судово-ветеринарна експертиза живої птиці, а також трупів птиці з ушкодженнями різного походження призначається правоохоронними органами під час досудового розслідування правопорушень, пов'язаних iз жорстоким поводженням 3 тваринами (Zabudskyi, 2020), незаконним полюванням, порушенням ветеринарних правил, порушенням правил використання об'єктів тваринного світу, порушенням вимог щодо охорони диких тварин, порушенням порядку обігу об'єктів тваринного світу, порушенням вимог щодо охорони видів тварин, занесених до Червоної книги України, порушенням правил щодо карантину тварин та інших ветеринарно-санітарних вимог тощо (Hernandez-Moreno et al., 2013; Zapara et al., 2019; Eggert et al., 2019; Yatsenko \& Derecha, 2019; Karris et al., 2020).

Необхідність в їх дослідженні виникає у випадках, коли їм заподіяна шкода здоров'ю у вигляді різних тілесних ушкоджень (Morrow et al., 2012), отруєнь свійської птиці як наслідок порушення умов і режиму годівлі (Botha et al., 2011; Crespo et al., 2008), отруєння дикої птиці (Raidal \& Jaensch, 2006; Kupper et al., 2007; Berny \& Gaillet, 2008), зоопаркової птиці (Pattee et al., 2006), утримання й використання, а також інших посягань на права тварин (Tauson, 1985; Smart et al., 2010; Millins et al., 2014).

Протиправні насильницькі дії щодо птиці можуть призвести до розладу їі здоров'я, каліцтва або смерті, що в Україні та інших країнах світу переслідуються законом та тягнуть адміністративну чи кримінальну відповідальність, адже це суперечить моральним засадам демократичного суспільства, які базуються на принципах гуманізму, забезпечення їхнього благополуччя і захисту від жорстокого поводження (Prange et al., 2000; Guitart et al., 2010; Yatsenko et al., 2019; Yatsenko et al., 2020).

Загальна структура висновку судового експерта регламентована у нормативному документі “Інструкція про призначення та проведення судових експертиз та експертних досліджень", затверджена Наказом Міністерства юстиції України 08.10.1998 № 53/5 (у редакції наказу Міністерства юстиції України від 26.12.2012 № 1950/5) (далі - Інструкція) (Instruktsiia pro pryznachennia i provedennia sudovykh ekspertyz, 2012).

Проте вона унормовує структуру висновку експерта для всіх видів судових експертиз, без зазначення особливостей, характерних для судово-ветеринарної експертизи. У зв'язку з тим, що в Україні судововетеринарна експертиза як вид прикладної експертної та наукової діяльності в системі експертного забезпечення правосуддя офіційно зареєстрована в Міністерстві юстиції в 2019 році, то нині розробка спеціальних судово-ветеринарних методик лише розпочата та перебуває на початковому етапі (Yatsenko et al., 2021). Крім того, не достатньо розроблені, а отже не затверджені методики проведення і оформлення результатів судово-ветеринарної експертизи різних об'єктів, у т. ч. трупів птиці, що часто призводить до неповного, обмеженого, досить узагальненого подання результатів дослідження експерта, а це своєю чергою позбавляє можливості суд та органи слідства сформувати об'єктивне і повне уявлення про обставини правопорушення та встановити істину. Проте встановлення правил укладання висновку експерта за результатами судово-ветеринарної експертизи 3 урахуванням особливостей ії об'єктів, методологічних засад надасть можливість уникнути експертних помилок, а отже потребує їх розроблення, систематизації, обгрунтування і впровадження в експертну практику для забезпечення правосуддя, що є надзвичайно актуальним питанням 3 теоретичної і практичної точок зору як в юриспруденції, так і в судово-ветеринарній експертизі.

Мета роботи - сформулювати та визначити особливості структури висновку експерта за результатами проведеної судово-ветеринарної експертизи трупа птиці.

\section{Матеріал і методи досліджень}

3 урахуванням специфіки теми, мети і завдань дослідження в роботі використано наукові методи, зокрема: формально-юридичний, діалектичний, системний аналіз, синтез, моделювання, аналіз висновків експертів. 
Емпіричну базу дослідження становить аналіз висновків експертів за результатами проведених судововетеринарних експертиз, проведених в Бюро судововетеринарних досліджень Харківської державної зооветеринарної академії протягом 2010-2021 років, а також в лабораторії криміналістичних досліджень Національного наукового центру "Харківський науково-дослідний інститут судових експертиз ім. Засл. проф. М. С. Бокаріуса" Міністерства юстиції України протягом 2017-2021 років.

Робота $\epsilon$ частиною наукових тем: “Теоретикоправові засади судово-ветеринарної експертизи тварин $з$ ознаками жорстокого поводження 3 ними", яка виконується на базі кафедри ветеринарно-санітарної експертизи та судової ветеринарної медицини Харківської державної зооветеринарної академії, державний реєстраційний номер - 0118U004677, а також "Розробка методики судово-ветеринарної експертизи трупів тварин”, яка виконується на базі Національного наукового центру “Інститут судових експертиз ім. Засл. проф. М. С. Бокаріуса”, державний реєстраційний номер - 0121U100299.

\section{Результати та їх обговорення}

В основу цієї наукової роботи покладено формулювання структури висновку судово-ветеринарного експерта за результатами судово-ветеринарної експертизи трупа птиці з урахуванням об'єкта, методів і алгоритмів та особливостей його дослідження.

Висновок експерта $є$ процесуальним документом, який засвідчує факт і хід дослідження експертом об'єктів, наданих йому уповноваженим органом або особою, укладений згідно зі встановленими нормативними вимогами та містить відповіді на питання, поставлені на вирішення експерту в процесуальному документі про призначення судової експертизи, засновані на спеціальних знаннях експерта.

Згідно 3 "Інструкцією про призначення та проведення судових експертиз та експертних досліджень” у висновку експерта обов'язково зазначають його реквізити, зокрема найменування документа (Висновок експерта), дати та номера його укладання, категорії експертизи (додаткова, повторна, комісійна, комплексна), виду експертизи (судово-ветеринарна).

Приклад: "Висновок експертів № $\underline{\mathrm{xx}}$ за результатами проведення комплексної судово-ветеринарної експертизи та дослідження наявності пестицидів у навколишньому середовищі за матеріалами досудового розслідування, внесеного до Єдиного реєстру досудових розслідувань за № $\operatorname{xxxxxxxxxxxxx}$ від (дата). Складено (дата)".

Висновок експерта за результатами проведеної судово-ветеринарної експертизи трупа птиці складається $з$ трьох частин: вступної, яка у висновку позначається як "Вступ", дослідницької - позначається у висновку як “Дослідження” і заключної, або підсумкової, позначається як "Висновки”.

Першою частиною висновку експерта є "Вступ", котрий містить формальний виклад інформації, джерелом якої $\epsilon$ документ про призначення судововетеринарної експертизи чи залучення експерта та перелік нормативно-правових актів і джерел літератури, які будуть використані експертом для обгрунтування висновку, проте не має містити будь-яких суб'єктивних суджень експерта (рис. 1).

Таким чином, у вступній частині висновку експерта зазначають:

1) дату надходження документа про призначення експертизи або залучення експерта, найменування експертної установи та/або ім'я, прізвище, по батькові експерта, документ про призначення експертизи або залучення експерта, його найменування і дату складання, найменування органу та/або посада і прізвище особи, який (яка) призначив(ла) судово-ветеринарну експертизу або залучив(ла) експерта, справу, за якою вона призначена (кримінальна, цивільна, господарська, тощо, номер справи, або стаття закону, якою передбачено надання висновку експерта (у разі наявносTi).

Приклад: “(дата) до Національного наукового центру "Інститут судових експертиз ім. Засл. проф. М. С. Бокаріуса" МЮ України надійшла постанова від (дата) про призначення судово-ветеринарної експертизи за матеріалами кримінального провадження

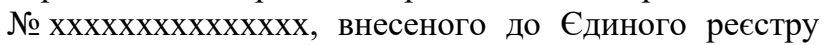
досудових розслідувань від (дата) від слідчого слідчого відділу (назва відділу полічіï, звання, прізвище та ініціали”).

2) перелік об'єктів, що підлягають дослідженню, та зразків (у разі надходження); відомості про надані матеріали: назва матеріалів чи документів та кількість аркушів:

Приклад: “Для проведення судово-ветеринарної експертизи надано: копію звіту про результати дослідження патологічного (біологічного) матеріалу №xxxxx п.м/хx від (дата) на 2 аркушах”.

3) спосіб доставки та вид упаковки досліджуваних об'єктів із зазначенням у необхідних випадках відомостей про те, чи впливав спосіб упаковки на їх збереженість:

Приклад: “Наданий для дослідження пакет виготовлений із цупкого паперу світло-коричневого кольору. На поверхні однієї зі сторін пакета утримується аркуш паперу білого кольору, на поверхні якого є друкований напис: “приводиться текст”. На поверхні верхньої частини зворотної сторони пакету, у місці закріплення вільного його кінця, є відбиток круглої печатки: “"риводиться текст, з відбитку печатки, ї̈ номер".

Зовнішній вигляд пакета 3 об'єктом для дослідження з боку друкованого напису та зворотної його сторони наведено на фото 1, фото 2, відповідно. 
Структура вступної частини висновку судово-ветеринарного експерта

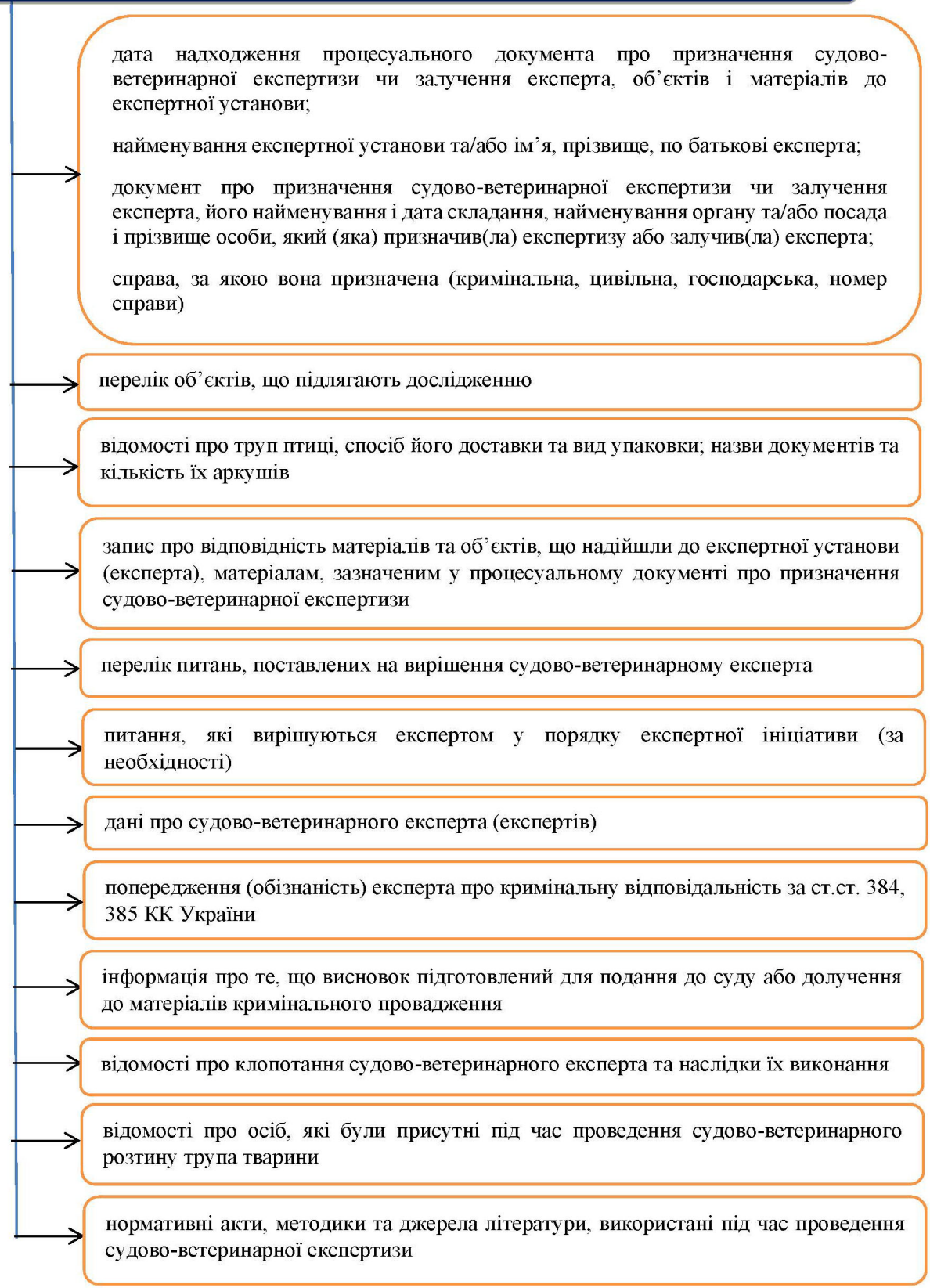

Рис. 1. Блок-схема структури вступної частини висновку судово-ветеринарного експерта

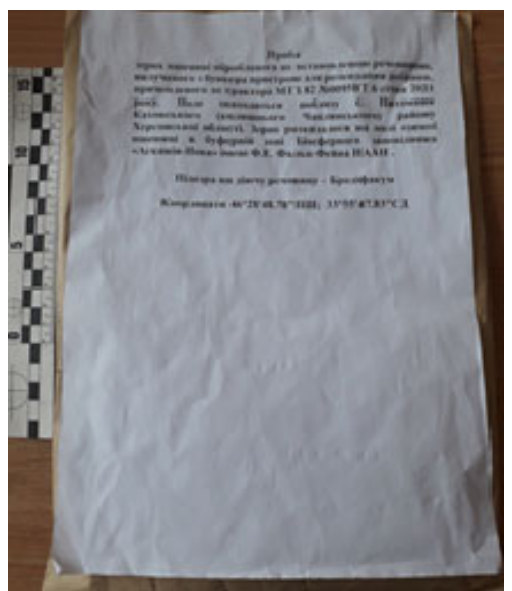

Фото 1. Зовнішній вигляд пакета з боку напису

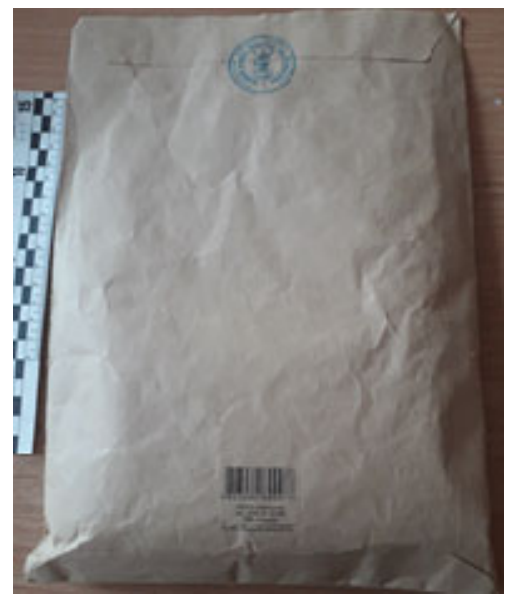

Фото 2. Зовнішній вигляд пакета зі зворотної сторони 
Трупи птиці № 1, 2, 3 запаковані в мішки білого кольору. Горловина кожного мішка прошита ниткою білого кольору. До кожного пакування кріпиться аркуш паперу білого кольору з нерозбірливим написом. “Цілісності пакування наданих об’єктів не порушено".

У разі проведення судово-ветеринарної експертизи ексгумованого трупа птиці про це у висновку експерта зазначають додатково.

Приклад: “Для дослідження експертам направлено ексгумований (дата) труп (вид птиці) під час огляду місця події (протокол огляду місця події від (дата). Труп птиці запакований у поліпропіленовий та поліетиленовий мішки (пакети). Горловина мішка склеєна липкою стрічкою, має етикетку з написом: (текст)".

4) запис про відповідність матеріалів та об'єктів, що надійшли до експертної установи або експерта, матеріалам, зазначеним у документі про призначення експертизи або залучення експерта.

Приклад: “Надані на дослідження об’єкти, а також матеріали кримінального провадження №xxxxxxxxxxxx (із зазначенням кількості аркушів чи сторінок) відповідають переліку, зазначеному в постанові слідчого від (дата)".

5) перелік питань цитують дослівно у формулюванні документа про призначення експертизи або залучення експерта, які поставлено на вирішення експерта, беручи їх у лапки.

Згідно із ч.9 n.4.12 Інструкції, якщо питання сформульовано незрозуміло, але зміст питання експертові зрозумілий, то після наведення питання в редакції документа про призначення експертизи або залучення експерта він може дати відповідні роз'яснення і викласти питання в іншій редакції, що відповідає загальноприйнятим або ж в редакції “Науковометодичних рекомендацій 3 питань підготовки та призначення судових експертиз та експертних досліджень" (Naukovo-metodychni rekomendatsii z pytan pidhotovky i pryznachennia sudovykh ekspertyz, 1998).

Якщо в процесуальному документі про призначення судово-ветеринарної експертизи поставлено кілька питань, судово-ветеринарний експерт має право згрупувати їх і викласти в послідовності, яка забезпечує найдоцільніший порядок дослідження.

Якщо деякі питання, що містяться в документі про призначення судово-ветеринарної експертизи, вирішувались під час проведенні експертиз різних видів, то додатково зазначаються відомості про ці експертизи, вказуючи найменування експертної установи, номер та дату висновку.

Якщо питання, які поставлені на вирішення судово-ветеринарної експертизи, доцільно вирішувати в іншому порядку, ніж той, що визначений у документі про призначення судово-ветеринарної експертизи чи залучення експерта, - зазначається, в якому порядку вирішуватимуться ці питання.

У разі, якщо в документі про призначення судововетеринарної експертизи є питання, що не належать до предмета судово-ветеринарної експертизи або виходять за межі компетенції експерта, указують причини, з яких ці питання не можуть бути вирішені, що відповідає вимогам $n .4 .13$ Інструкції.

Перелік питань, поставлених на вирішення експерта, у висновку приводять 3 таким заголовком: "Питання, поставлені для вирішення експертом". Вирішення питань, що ставлять судово-ветеринарному експерту, під час дослідження трупа птиці, в основному, залежить від виду птиці, способу вчинення правопорушення, методів маскування злочинного результату, конкретної слідчої ситуації.

Під час дослідження трупа птиці з ознаками насильницької смерті нами розроблені й обгрунтовані типові питання, серед яких такі:

- До якого виду належить труп дослідженої птиці?

- Якої статі, віку труп(и) тварин(и), які їх фізіологічні особливості?

- Які тілесні ушкодження виявлені в трупі птиці, яка їх локалізація і характер?

- Який механізм та яка черговість спричинення тілесних ушкоджень, виявлених в трупі птиці?

- Що стало причиною смерті птиці?

- Прижиттєвий чи посмертний характер носять ушкоджень, виявлені в трупі птиці?

- Яка давність утворення ушкоджень, виявлених в трупі птиці?

- Якого ступеня тяжкості шкода, заподіяна здоров'ю птиці внаслідок ушкодження?

- Чи могли ушкодження, виявлені в трупі птиці, призвести до смертельних наслідків?

- Чи є виявлені в трупі птиці тілесні ушкодження каліцтвом?

- Чи є на трупі птиці характерні ознаки, за якими можна встановити характер та особливості зброї чи інших знарядь, якими спричинені ушкодження?

- Який причинно-наслідковий зв'язок між виявленими тілесними ушкодженнями і смертю птиці?

- Чи могли ушкодження, виявлені в трупі птиці, утворитися самостійно під час іiі життя, без стороннього втручання?

- Чи могли виявлені ушкодження виникнути в результаті насильницьких дій над твариною(ами)?

- Чи вплинули наслідки виявлених ушкоджень на якість життя птиці?

- Чи спричинили виявлені ушкодження фізичний біль, страждання і мучення птиці перед смертю?

Перелік запропонованих питань не $є$ вичерпним, він може змінюватись залежно від виду птиці, умов іiі мешкання, виду виявлених тілесних ушкоджень тощо.

6) питання, які вирішуються експертом у порядку експертної ініціативи, якщо таке розглядалось:

Приклад: "Відповідно до п. 4.14 "ІІнструкції про призначення i проведення судових експертиз та експертних досліджень, судово-ветеринарним експертом у порядку експертної ініціативи вирішується питання № хx: Чи могли ушкодження, виявлені в трупі птиці, утворитися самостійно під час іiі життя, без постороннього втручання?".

За наявності в документі про призначення судововетеринарної експертизи питань, які не належать до предмета експертизи або не входять до компетенції експерта, - зазначають причини, з яких ці питання не 
вирішувались.

7) дані про судово-ветеринарного експерта (якщо первинна, додаткова чи повторна судово-ветеринарна експертиза виконувалась експертом одноосібно) або експертів (якщо виконувалась комісійна чи комплексна судово-ветеринарна експертиза), зазначаючи його (ï) прізвище, ім'я та по батькові, посаду, клас, науковий ступінь та вчене звання, освіту, освітньокваліфікаційний рівень, експертну спеціальність, стаж експертної роботи, дату та номер видачі свідоцтва про присвоєння кваліфікації судового експерта, ким видано та строк його дії:

Приклад: “Проведення експертизи доручено: судовому експерту 2-го кваліфікаційного класу, провідному науковому співробітнику сектору біологічних, ветеринарних та грунтознавчих досліджень лабораторії криміналістичних досліджень Національного наукового центру "Інститут судових експертиз ім. Засл. проф. М. С. Бокаріуса”, доктору ветеринарних наук, професору Яценку Івану Володимировичу, який має вищу ветеринарну і юридичну освіту, кваліфікацію судового експерта за спеціальністю 18.1 «Ветеринарні дослідження» (посвідчення № хххх, видане рішенням експертно-кваліфікаційної комісії Харківського науково-дослідного інституту судових експертиз ім. Засл. проф. М. С. Бокаріуса від (дата), дійсне до (дата). Стаж експертної роботи - 32017 р., загальний стаж роботи в сфері ветеринарної медицини - з 1993 р.”

Висновок експерта під час проведення комісійної або комплексної експертизи складається 3 урахуванням таких особливостей: у вступній частині додатково зазначають дані про голову комісії експертів та відомості про експертизи, результати яких задані органом (особою), який(яка) призначив(ла) експертизу або залучив(ла) експерта, як вихідні дані.

Приклад: "Проведення експертизи доручено комісії експертів:

- Експерту 1 - судовому експерту 2-го кваліфікаційного класу, провідному науковому співробітнику сектору біологічних, ветеринарних та грунтознавчих досліджень, лабораторії криміналістичних досліджень ННЦ “ІСЕ ім. Засл. проф. М.С. Бокаріуса", доктору ветеринарних наук, професору, академіку Національної академії наук вищої освіти України, який має вищу ветеринарну і юридичну освіту, кваліфікацію судового експерта за спеціальністю 18.1 "Ветеринарні дослідження” (свідоцтво № хххх, видане ЕКК Харківського НДІСЕ МЮ України (дата), дійсне до (дата)). Стаж експертної роботи - 32017 р., загальний стаж роботи в сфері ветеринарної медицини - з 1993 р. голова комісії;

- Експерту 2 - судовому експерту 3-го кваліфікаційного класу, завідувачу сектору біологічних, ветеринарних та грунтознавчих досліджень, лабораторії криміналістичних досліджень ННЦ "ICE ім. Засл. проф. М. С. Бокаріуса", кандидату ветеринарних наук, який має вищу ветеринарну освіту, кваліфікацію судового експерта за спеціальністю 18.1 "Ветеринарні дослідження" (свідоцтво № хххх, видане ЕКК Харківського НДІСЕ МЮ України (дата), дійсне до (дата)).
Стаж експертної роботи - з 2019 року, загальний стаж роботи в сфері ветеринарної медицини - з 2007 р.;

- Експерту 3 - старшому судовому експерту 1-го кваліфікаційного класу сектору фізичних та хімічних досліджень лабораторії криміналістичних досліджень, який має вищу фармацевтичну освіту, кваліфікацію судового експерта за спеціальністю 8.10.1 “Дослідження наявності пестицидів у навколишньому середовищі” (свідоцтво № хxхx, видане рішенням експертно-кваліфікаційної комісії Харківського науководослідного інституту судових експертиз ім. Засл. проф. М. С. Бокаріуса МЮ України від (дата), дійсне до (дата)), стаж експертної роботи за спеціальністю 3 2019 року.

Експерти 1, 2 проводили судово-ветеринарне дослідження. Експерт 3 проводив хімічні дослідження й вирішував в комплексі питання № 8 зазначені у постанові”.

8) попередження (обізнаність) експерта чи експертів про кримінальну відповідальність, відповідно до вимог ст. 70 та ч.2 ст. 102 Кримінального процесуального кодексу України, за надання завідомо неправдивого висновку за статтею 384 Кримінального кодексу України або за відмову від надання висновку за статтею 385 цього ж кодексу.

Приклад: “Відповідно до вимог ст. 70 та ч.2 ст. 102 Кримінального процесуального кодексу України експерт про відповідальність за завідомо неправдивий висновок та відмову без поважних причин від виконання покладених на нього обов'язків за ст. 384 та ст. 385 Кримінального кодексу України попереджений _(особистий підпис)__ /Прізвище, ініціали/.

9) інформація про те, що висновок підготований для подання до суду або долучення до матеріалів кримінального провадження (у разі проведення експертизи на підставі письмового звернення особи).

10) відомості про клопотання судововетеринарного експерта та наслідки їх розгляду (дата направлення клопотання експерта про надання додаткових матеріалів, дата надходження до експертної установи додаткових матеріалів або відомостей про наслідки розгляду клопотання; обставини, які мають значення для надання висновку, з обов'язковим зазначенням джерела їх отримання).

Приклад: “(дата) старшому слідчому (найменування відділу полічіi) (зазначають звання слідчого та його прізвище, ім'я, по батькові) було направлено клопотання про надання необхідних для судововетеринарного дослідження об'єктів, зокрема: труп сірого журавля № 1, труп сірого журавля № 2, труп сірого журавля № 3 та вилучені оброблені зерна пшениці, які поміщено до сейф пакету № $\operatorname{xxxxxx.~Клопо-~}$ тання експерта задоволене. (дата) до (назва експертної установи) 3 (найменування відділу поліиіі) від слідчого (зазначають звання слідчого та його прізвищее, ім'я, по батькові) надійшли необхідні для дослідження об'єкти, зокрема: труп сірого журавля № 1, труп сірого журавля № 2, труп сірого журавля № 3 та вилучені оброблені зерна пшениці, які поміщено до

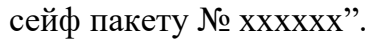


У разі, якщо проводилась додаткова або повторна експертиза, зазначають відомості про первинну чи попередні експертизи, вказуючи прізвище та ініціали експерта, назву експертної установи чи місце роботи експерта, номер і дату висновку експерта, зміст заключних висновків первинної експертизи чи висновків експертів попередніх експертиз; зміст питань, які були поставлені перед судовим експертом на додаткове або повторне вирішення, а також мотиви призначення додаткової або повторної судово-ветеринарної експертизи, які зазначені у документі про призначення цієї експертизи. Якщо у ньому такі мотиви відсутні, про це роблять відповідний запис.

12) відомості про підстави та осіб, які були присутні під час проведення судово-ветеринарного розтину трупа птиці (прізвище, ініціали, статус).

Приклад: "Під час проведення судововетеринарного розтину трупів птахів був присутній слідчий (зазначають найменування відділу поліиії, вказують звання слідчого та його прізвище, ім'я, по батькові)".

13) нормативні акти та джерела літератури, використані під час проведення судово-ветеринарної експертизи.

Приклад: “1. Яценко I. В., Париловський О. I. Приходько I. Судово-ветеринарні ознаки шкоди здоров'ю, небезпечної для життя тварини. Ветеринарія, технології тваринництва та природокористування: науково-практичний журнал. 2019. № 5. С. 239-245. DOI: $10.31890 /$ vttp.2020.05.42.

2. Яценко I. В., Париловський О. І., Жиліна В. М. Порядок судово-ветеринарного встановлення ступеня тяжкості шкоди, заподіяної здоров'ю тварини. Науковий вісник Львівського національного університету ветеринарної медицини та біотехнологій імені С. 3. Гжицького. Серія: Ветеринарні науки. 2020. 22 (99). 182-192. DOI: 10.32718/nvlvet9928.

3. Париловський О. І., Яценко I. В., Богатирьова А. М. Судово-ветеринарна характеристика ознак шкоди, заподіяної здоров'ю тварини середньої тяжкості. German International Journal of Modern Science. 2021. № 4. C. 70-75. DOI: 10.24412/2701-8377-2021-4-1-7075.

4. Яценко I. В., Казанцев Р. Г. (2021). Порядок проведення судово-ветеринарної експертизи трупів тварин в секційній залі спеціалізованої експертної установи. Ветеринарія, технології тваринництва та природокористування. 7, 179-191. DOI: 0.31890/vttp.2021.07.28”.

Друга частина висновку експерта за результатами проведеної судово-ветеринарної експертизи трупа птиці носить назву “Дослідження”. Структура цієї частини висновку експерта регламентована n.4.13 Інструкції (Instruktsiia pro pryznachennia i provedennia sudovykh ekspertyz, 1998).

В цій частині судово-ветеринарний експерт викладає:

- відомості про стан трупів птиці, які надійшли на дослідження;

- у умови проведення судово-ветеринарних досліджень;
- застосовані методи (методики) дослідження, їхні реєстраційні номери (за наявності);

- основні етапи дослідження трупа птиці;

- посилання на ілюстрації, додатки та необхідні роз'яснення до них;

- результати, отримані під час цієї процедури та їх експертну оцінку, тобто обгрунтування здобутих результатів;

- причини розбіжностей з висновками попередніх експертиз, якщо такі розбіжності були виявлені.

Загальну структуру дослідницької частини висновку судово-ветеринарного експерта за результатами судово-ветеринарного дослідження трупа птиці визначає судово-ветеринарний експерт, відповідно до завдань та стану об'єкта чи об'єктів дослідження (рис. 2).

У дослідницькій частині виокремлюють такі розділи:

1. У підрозділі “Дослідження обставин справи i анамнез смерті птиці” викладають необхідні відомості, отримані з процесуального документа про призначення судово-ветеринарної експертизи чи із ветеринарних документів (виписки з історії хвороби підекспертної птиці тощо). Дослідженням анамнезу смерті птиці судово-ветеринарний експерт з'ясовує обставини, за яких тварина могла отримати смертельні механічні ушкодження чи бути отруєною; дату смерті; описує місце виявлення трупа, обставини, встановлені під час огляду трупа на місці його виявлення або інші обставини смерті птиці.

Приклад: Із постанови слідчого слідчого відділення (повна назва) звання, П.І.П. відомо, що “(дата) до чергової частини (повна назва відділу полічіiі) надійшло повідомлення зі служби “102” про те, що (дата) о 10:15 год. за адресою: (зазначається адреса) було виявлено три трупи лебедів білих".

2. Дослідження протоколу огляду місця події та ветеринарних документів, що стсоуються судововетеринарної експертизи та містяться в матеріалах справи або надані експерту додатково за його клопотанням, наприклад, дослідження протоколу обстеження птиці за життя фахівцями ветеринарної медицини (вказують назву лікарні чи клініки ветеринарної медицини, іiі юридичну адресу, прізвище, ім'я, по батькові фахівця ветеринарної медицини, який проводив обстеження птиці), протокол ультразвукового, гастроскопічного, рентгенологічного дослідження тощо, результати гематологічного, мікробіологічного чи паразитологічного дослідження, дослідження обставин смерті (як витяг з постанови слідчого) тощо.

3. Судово-ветеринарне дослідження трупа птиці, яке містить такі підрозділи:

A. Реєстраційні дані.

Б. Судово-ветеринарне дослідження трупа птиці станом на (дата).

B. Додаткові дослідження.

Г. Судово-ветеринарний діагноз.

Синтезуюча частина.

У підрозділі $\boldsymbol{A}$ “Реєстраційні дані” відображають розпізнавальні ознаки трупа птиці, зазначаючи: iї вид (курка, качка, індик тощо), стать: самець чи самка, 
породу, крос, лінію; окрас пір'я, масу трупа, вік, тип використання (наприклад, м'ясна або яйценосна порода курей; дика чи домашня птиця тощо), дані про власника птиці (за наявності), клінічний діагноз (за наявності), дату смерті, дату і місце проведення судово-ветеринарного розтину трупа птиці.

Приклад: "Реєстраційні дані:

1. Вид тварини - лебідь-шипун (Cygnus olor).

2. Стать - самка.

4. Вік - до 3-х років, доросла сформована птиця.

5. Маса трупа -7 кг 760 г

6. Окрас пір'я - білий.

7. Належить - вільно проживаюча у природі.

8. Дата смерті - 15 січеня 2021 р.”.
В підрозділі Б. “Судово-ветеринарне дослідження трупа птиці станом на (дата)” реєструють об'єктивні дані, отримані судово-ветеринарним експертом під час дослідження. Констатують не лише знайдені травматичні чи хворобливі зміни, а й нормальний стан окремих органів, тканин і частин тіла, сторонні запахи тощо, а й відсутність змін чи особливостей, що мають значення у конкретному випадку (відсутність ушкоджень, крововиливів, сторонніх запахів тощо). При цьому не допускається підміна докладного описання органа діагнозами типу “абсцес”, “набряк”, “обвуглення”, такі вирази, як: “в нормі”, “без особливостей” тощо.

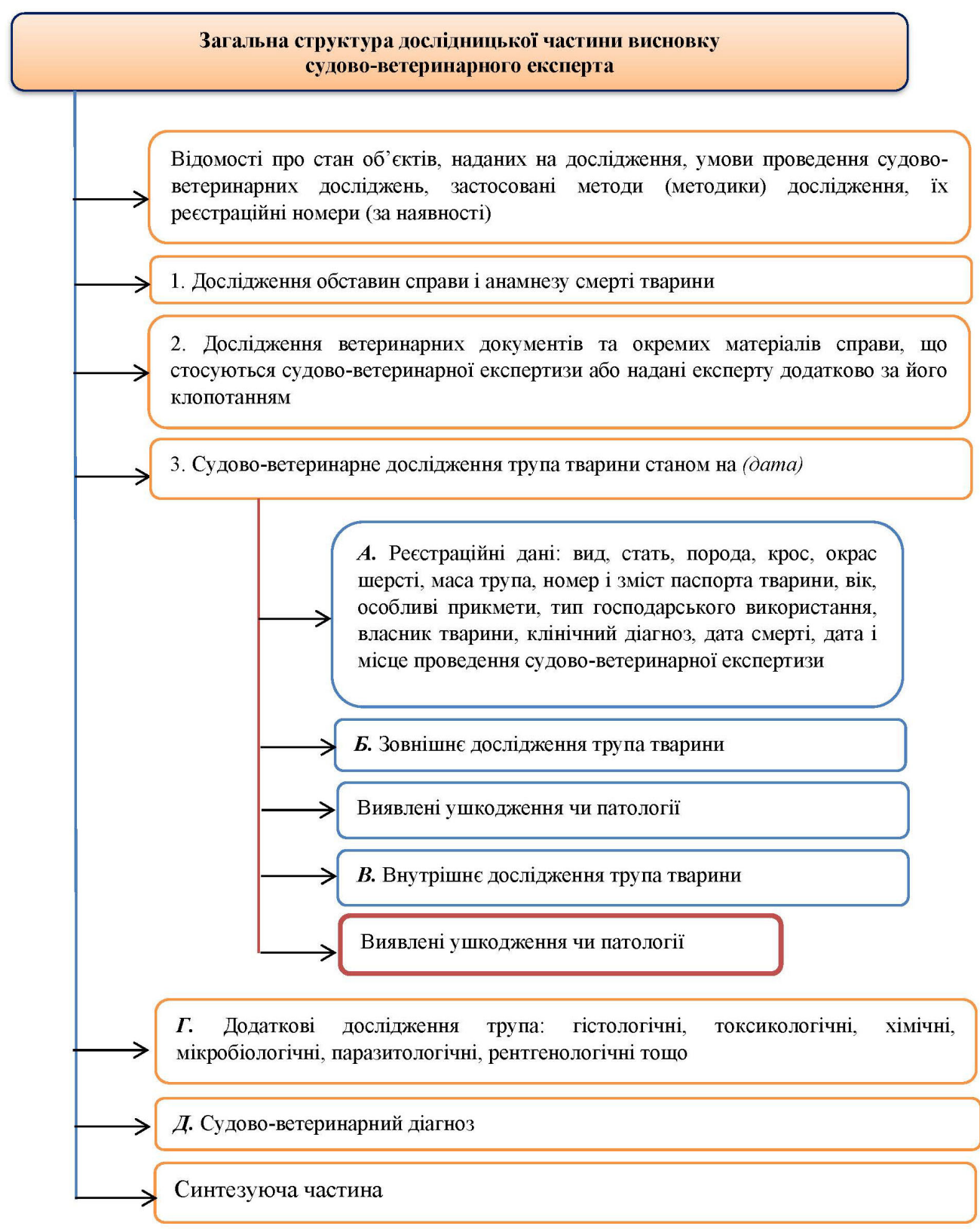

Рис. 2. Блок-схема загальної структури дослідницької частини висновку судово-ветеринарного експерта

Методичні підходи до викладення результатів судово-ветеринарного дослідження трупа птиці у висновку експерта можуть змінюватися залежно від особливостей питань, поставлених на вирішення експерту у процесуальному документі про призначення судово-ветеринарної експертизи, обставин спричи- 
нення і особливостей виявлених патологій, смертельних ушкоджень, заподіяних тварині, виду, віку птиці тощо.

За судово-ветеринарного розтину трупа птиці обов'язково проводять дослідження не менше двох порожнин тіла (грудо-черевної і черепної), а в порожнинах - дослідження всіх органів. Під час описання органів трупа птиці можна групувати однотипні ушкодження за ділянками із обов'язковим зазначенням їхньої кількості й розмірів у кожній ділянці.

Під час описання результатів зовнішнього і внутрішнього дослідження трупа i його органів об'єктивність викладу досягається методично правильним дослідженням і описом основних параметрів стану органів: розташування в порожнині тіла, величини і форми, кольору, консистенції, рисунка тканин як із зовнішньої поверхні органа, так і на розрізі. За наявності запаху зазначають його особливості. Описуючи стан природних отворів, констатують: вони закриті, напіввідкриті чи відкриті, вказують наявність виділень із них. Зазначають кількість рідини в порожнинах тіла, іiі властивості (колір, консистенція, прозорість, домішки тощо). Під час опису органів, будьяких патологічно змінених ділянок тіла спочатку зазначають їхню довжину, товщину, масу. Під час описання парних органів спочатку наводять їхню загальну характеристику, а потім докладно описують зміни в кожному з них. У непарних органах після загальної характеристики зазначають вогнищеві зміни, їх локалізацію та характер.

У розділі “Зовнішне дослідження трупа” викладають дані про зовнішній вигляд трупа, за схемою, котра включає дані про тілобудову, конституцію, вгодованість, стан трупного охолодження та заклякання, вираженість ознак гниття трупа.

Приклад: “Труп лебедя білого, самки, середньої вгодованості. Грудні й тазові кінцівки витягнуті, зігнуті у суглобах. Тілобудова пропорційна, правильна. Трупне задубіння не виражене в усіх звичайно досліджуваних групах м'язів. Охолодження трупа повне, рівномірне. М'які тканини м'якої консистенції. Ознаки трупного гниття ззовні відсутні”.

Зовнішнє дослідження частин тіла і органів трупа описують за такою схемою: дослідження видимих слизових оболонок, пір'яного покриву, шкіри, ступеня розвитку підшкірної клітковини, органів ротової порожнини, очей, носа, шиї, клоаки, грудних і тазових кінцівок, хребта й грудної клітки, анатомічної цілісності голови. Підсумовують вказівкою на виявлені ушкодження чи патології.

Результати зовнішнього дослідження трупа птиці розпочинають із зазначення стану видимої частини слизових оболонок (очей і ротової порожнин), зазначають стан пір'я (колір, густина, ступінь прилягання до шкіри, скуйовдженість, вираженість линьки); стан шкіри (пігментованість, колір, еластичність, вологість, запах; стан розвитку підшкірної клітковини).

Приклад: "Пір'яний покрив сіро-білого окрасу, густий, тьмяний, рівномірно покриває тіло, линька помірна, пір'я добре фіксоване у фолікулах. Воно забруднене залишками речовини, зовні схожої на грунт.
Шкіра анатомічно цілісна, без ушкоджень, еластична, тонка. Куприкова залоза міститься в ділянці хвоста, вона добре розвинута. Рогові лусочки плесна i пальці темно-сірого кольору, щільно прилягають одна до одної. Шкіра блідо-жовтого кольору, суха та дещо забруднена речовиною, зовні схожою на грунт. Гнильний запах відсутній”.

Далі описують стан органів ротової порожнини, доступних для зовнішнього дослідження. Зазначають, який стан рота (закритий чи відкритий), наявність сторонніх предметів в ротовій порожнині, вказують на колір і рельєф слизової оболонки, наявність виразок $\mathrm{i}$ нашарувань.

Описуючи у висновку експерта стан язика трупа птиці, зазначають його топографічне положення в ротовій порожнині, чи виступає він за ії межі, анатомічну цілісність, стан слизової оболонки (колір, вологість, рельєф, наявність чи відсутність крововиливів, виразок тощо).

Приклад: “Ротовий отвір щільно закритий, язик 3 ротової порожнини не виступає. Поверхня дзьоба тьмяна та тверда. В ротовій порожнині виявляється речовина бурого кольору, зовні схожа на кров. Кормові маси в ній відсутні. Ротова щілина знаходиться в закритому стані. Язик без ушкоджень і деформацій, розміщений на дні ротової порожнини, пружної консистенції, помірно вологий. Слизова оболонка ротової порожнини та іiі органів блідо-рожевого кольору, помірно волога й блискуча. Ротова порожнина без вмісту".

Описуючи в дослідницькій частині висновок експерта стан очей трупа птиці, зазначають стан очних щілин (закриті чи відкриті), кон'юнктиви і рогівки (вказують на анатомічну цілісність, колір, вологість, наявність крововиливів, виразок), наявність і характер виділень 3 очей.

Приклад: “Очні щілини відкриті, очні яблука деформовані, сухі. Кон’юнктива - сірого кольору, без крововиливів".

Описуючи стан зовнішнього вуха трупа птиці, зазначають прохідність зовнішніх слухових проходів і наявність в них сторонніх предметів.

Описуючи стан носа, вказують на стан дзьоба навколо ніздрів, прохідність останніх, акцентують увагу на анатомічній цілісності носа, прохідності носових ходів.

Приклад: "Ніздрі та носові ходи вільнопрохідні. Виділення 3 носових отворів та сторонній вміст відсутні. Дзьоб анатомічно цілісний”.

Описуючи у висновку експерта стан шиї трупа, зазначають іiі пропорційність тулубу, а описуючи форму грудної клітки, звертають увагу на цілісність ребер, тазових кісток, а крім того, оцінюють форму й консистенцію грудочеревної стінки на дотик.

Приклад: “Шия розвинута пропорційно тулубу. Грудна клітка плоско-циліндричної форми (фото № х). Ребра, хребет, тазові кістки на дотик цілі. Грудочеревна стінка в без реберній ділянці м'яка".

Описуючи стан грудних і тазових кінцівок, зазначають правильність їх розвитку, цілісність кісток, стан кігтів та шпор, їх консистенцію на дотик. 
Приклад: "Грудні та тазові кінцівки розвинуті правильно, кістки їх на дотик анатомічно цілісні. Кігті та шпори на тазових кінцівках анатомічно цілісні, щільні”.

Описуючи стан зовнішнього отвору клоаки, зазначають його стан (закритий, відкритий чи напіввідкритий), чи забруднене пір'я навколо цього отвору каловими масами, вказують на колір слизової оболонки, іiі цілісність.

Приклад: “Зовнішній отвір клоаки не замкнений, слизова оболонка іiі сіро-червоного кольору, анатомічно цілісна, шкіра навколо нього забруднена послідом".

В кінці розділу “Зовнішнє дослідження трупа" описують всі ушкодження чи патології, виявлені під час зовнішнього дослідження трупа. Приклад: "УШКОДЖЕННЯ під час зовнішнього дослідження трупа не виявлені”, або “УШКОДЖЕННЯ: рани, в яких виявлено сторонні металеві предмети округлої форми: в ділянці тазу (шпротинка №1), в ділянці 1-го ребра (шпротинка № 2), в ділянці грудної клітки на рівні шостого ребра (шпротинка № 3), в ділянці лівого плеча (шпротинка № 4)”.

Розділ дослідницької частини висновку експерта під назвою "Внутрішне дослідження трупа птиці" включає описання грудочеревної порожнини, положення органів у ній, а також детально описують кожний орган з акцентом на ушкодження чи патологічні вогнища (рис. 3).

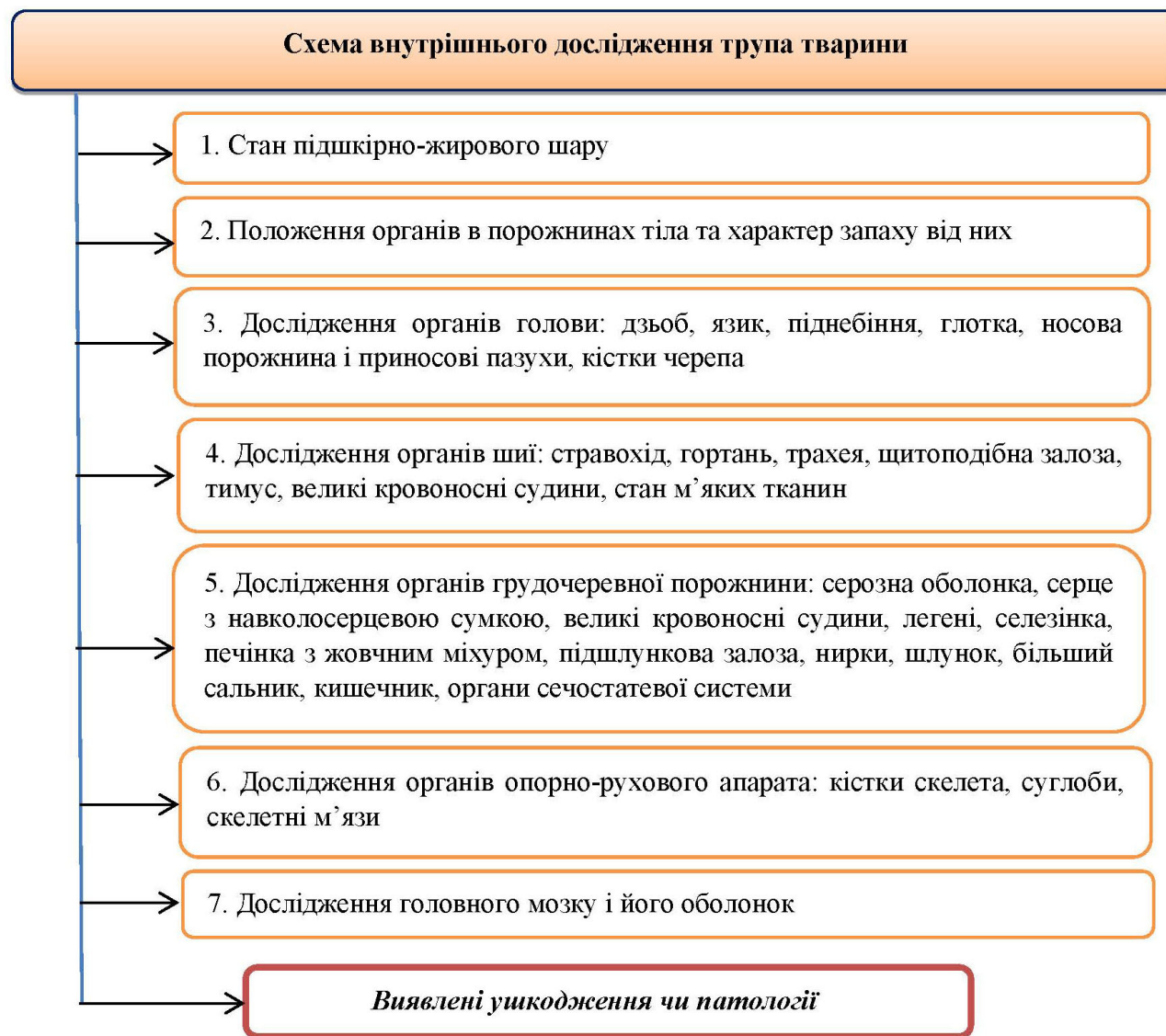

Рис. 3. Блок-схема внутрішнього дослідження трупа птиці

Описуючи у висновку експерта стан підшкірножирового шару, ступінь його розвитку, оцінюють колір жиру, його консистенцію, вологість, наповненість кров'ю кровоносних судин, наявність крововиливів, їх локалізацію та розміри.

Приклад: "Підшкірна жирова клітковина добре розвинута, сіро-зеленого кольору”.

Описуючи стан органів шиї, звертають увагу на положення органів і стан м'яких тканин. Зазвичай серед органів шиї описують стан стравоходу, гортані, трахеї, великих кровоносних судин (правої та лівої загальної сонної артерії, яремні вени), м’яких тканин за схемою описання трубкоподібних органів, вказуючи на колір і складчастість слизової оболонки, наявність чи відсутність в їх просвіті сторонніх предметів, а також тимуса, щитоподібної залози, лімфатичних вузлів (у водоплавної птиці), слинних залоз - за схемою описання паренхіматозних органів, зазначаючи їхню форму, колір ззовні й на розрізі, консистенцію, наявність чи відсутність ушкоджень.

Приклад: “Органи шиї займають природне анатомічне положення. М'які тканини шиї без ушкоджень. Головні бронхи $і$ гортань природної трубкоподібної форми, їх адвентиція сірого кольору. Слизова оболонка гладенька, помірно волога. Вони вільно прохідні, сторонній вміст відсутній. Трахея циліндричної форми, iii хрящові кільця помірно еластичні. Слизова оболонка помірно волога, блискуча, блідо-рожевого кольору. Ушкодження та деформації відсутні. Прохідність не порушена. Стравохід трубкоподібної фор- 
ми. Він розміщений топографічно правильно. Просвіт стравоходу не містить корму, а також стороннього вмісту, його прохідність не порушена. Слизова оболонка волога, на її поверхні є незначна кількість слизу, іiі колір - блідо-рожевий з сіруватим відтінком, чиста. Патологічні зміни відсутні”.

Порожнини трупа птиці у висновку експерта описують за схемою: наявність стороннього запаху, стан серозної оболонки: вологість, рельєф, колір, прозорість, нашарування, спайки, кровонаповненість кровоносних судини, крововиливи та їхня локалізація; потовщення, спайки з органами. Сторонній вміст в серозних порожнинах трупа птиці описують за такою схемою: об'єм (см³), колір, наявність в ньому домішки крові, фібрину, кормових і калових мас, паразитів, його консистенція, склад, зазначають характер, запах газів, вказують на виявлені сторонніх предметів та ушкоджень, їх характер, локалізацію, розміри. За необхідності зазначають результати проведеного мікроскопічного та бактеріологічного дослідження випоту з порожнин тіла.

Приклад: “В грудо-черевній порожнині тіла міститься речовина рожевого кольору, зовні схожа на кров (фото № $x$ ). Гнилісний запах від трупа відсутній”.

Положення внутрішніх органів може бути природним (анатомічно правильним), або певні органи зміщені в межах порожнини тіла, або за іï межі (у разі випадіння органів). Обов'язково зазначають наявність ознак трупного аутолізу.

Приклад: “Внутрішні органи займають природне анатомічне положення. Вони дещо бліді (фото № х). Поверхня серозної оболонки грудочеревної порожнини тіла помірно волога, гладенька та блискуча, зі слабко кровонаповненими кровоносними судинами. Реєструються скупчення підсерозного внутрішнього жиру, м'якої консистенції, світло-жовтого кольору, забрудненого кров'ю”.

В грудочеревній порожнині тіла обов'язковому описанню підлягають такі органи: серозна оболонка, навколосерцева сумка, серце, великі кровоносні судини, легені, селезінка, печінка, жовчний міхур, підшлункова залоза, шлунок, більший сальник, кишечник, нирки, надниркові залози, сечоводи, сечовий міхур; сім'яники $з$ придатками, сім'япроводи, яєчники, яйцепроводи.

Описання паренхіматозних органів (легень, печінки, нирок, селезінки, підшлункової залози, надниркових залоз, щитоподібної залози, яєчників, сім'яників тощо) здійснюють за схемою: форма, колір, консистенція, величина органа (визначається за станом країв, напруженості капсули органа, станом паренхіми під час розрізу капсули (збільшення об’єму, випинання паренхіми в ділянці розрізу; за результатом вимірювання і зважування враховують лінійні розміри, масу); стан капсули і серозної оболонки (колір, товщина, прозорість, кровонаповнення судин, нашарування на поверхні, ушкодження); стан тканин органа на розрізі: вид поверхні розрізу (колір, ступінь кровонаповнення судин, виразність анатомічних структур, рисунка будови, вологість, характер рідини що стікає з повер- хні розрізу, зіскрібок паренхіми); стан оточуючих м'яких тканин.

Описання трубкоподібних органів здійснюють за схемою: положення органів (природне чи зміщене), величина, форма, вміст органа (кількість, консистенція, колір, запах, склад), слизова оболонка (товщина, колір, характер секрету (нашарування), рельєф, відшарування від підлеглих тканин, наявність виразок), стан м'язової та серозної оболонок, ступінь кровонаповнення судин стінки органа.

Під час опису уражених ділянок зазначають: локалізацію вогнища ураження (розшарування тканини кров'ю, гноєм, наявність порожнин і їхній вміст, наявність пухлиноподібних утворень, осередки некрозу, дистрофічних змін, перелом кісток, вказують їхню кількість, величину, форму, консистенцію, колір, рисунок будови тканин в осередках ураження; реакцію оточуючих тканин).

Описуючи серце, експерт зазначає зміни його об'єму (збільшене, не збільшене, зменшене), форму (конічна в незміненого серця), в тому числі конфігурацію верхівки (незмінена, загострена, притуплена), консистенцію міокарда (пружна, в'яла, ущільнена), колір (рожево-червоний, блідо-червоний, темночервоний), стан перикарду та перикардіальної порожнини (блиск, рівність поверхні, нашарування, наявність та кількість рідкого вмісту), співвідношення товщини стінок шлуночків (в незміненому серці - 3:1, лівого до правого), розміри серцевих камер, ступінь кровонаповнення судин стінки серця (недостатне, помірне, надмірне), відхилення від трупної норми.

Приклад: “Серие знаходиться в серцевій сумці, воно конусоподібної форми, чотирикамерне, темночервоного однорідного забарвлення. Співвідношення товщини стінок правого і лівого шлуночків становить 1:3. Ділянка вінцевої борозни із жировими скупченнями. Коронарні судини помірно кровонаповнені. Розміри серцевих камер відповідають природній віковій нормі. Перикард легко відділяється від серця, він дещо матовий, вологий, прозорий, гладенький. В його порожнині міститься 1-2 краплі прозорої рідини. Кровонаповненість його кровоносних судин - помірна. Відсутній будь-який сторонній вміст. Колір - бурий, консистенція - дрябла. На оболонках серця реєструються крововиливи. Кровоносні судини епікарду помірно наповнені. Сам епікард гладенький, блискучий, тонкий. Міокард помірно дряблої консистенції, бурого кольору з крапковим крововиливами. Поверхня ендокарду блискуча, гладенька та волога. Серцеві клапани еластичні, блискучі, сірого кольору, мають тонкі та рівні краї. В порожнинах правого шлуночка i правого передсердя реєструється незначна кількість крові. Великі артерії блідо-жовтуватого забарвлення, типової трубчастої форми, в їхньому просвіті вміст відсутній. Невелика кількість крові, що не зсілася, міститься в порожнистих венах".

Описання легень птиці включає характеристику їх розмірів (зменшені, збільшені, не змінені), кольору (червоний, рожевий, сірий тощо), консистенції (еластична, пружна, ущільнена, пухка, крепітуюча, щільна, тістоподібна, повітряна), стану країв (гострі, тупі), 
повітроносних мішків, а також опис патологічних процесів та станів за наявності.

Приклад: “Легені відносно малі. Їх поділ на частки не виражений. Вони локалізуються у верхній четвертині порожнини тіла, занурюючись на певну глибину у міжреберні проміжки. Колір легень - яскраворожевий, природної прямокутної форми. Їхня консистенція - пухка, вони помірно кровонаповненні, із характерним виглядом поверхні розрізу.

Дев'ять повітроносних мішків є тонкостінними виростами ектобронхів. Їхні стінки прозорі, тоненькі, дещо матові, помірно вологі, без стороннього вмісту. Поблизу входу в грудну клітку міститься воло - мішкоподібне розширення стравоходу. Воно добре розвинуте, всередині кормові маси відсутні. Його слизова оболонка блідо-рожевого кольору, волога, складчаста".

Описуючи печінку птиці, експерт констатує її розміри (збільшені, дещо збільшені, зменшені, не змінені), консистенцію (щільна, помірно щільна, в'яла), краї (гострі, тупі), колір (коричневий, світлокоричневий, червоний тощо), описує виявлені патологічні процеси.

Приклад: “Печінка природно поділена на ліву латеральну і медіальну частки та праву частку. Ї̈̈ консистенція - помірно пружна, колір - світло-коричневий, анемічна. Її краї гострі. Жовчний міхур міститься на правій частці печінці. Його форма - видовженогрушоподібна, стінка тоненька. Він заповнений жовчю темно-зеленого кольору, водянистої консистенції. Поверхня слизової оболонки жовчного міхура сірозеленуватого кольору, має природній, дещо складчастий рельєф”.

Описуючи селезінку трупа птиці, експерт зазначає ii анатомічне положення (анатомічно правильне чи зміщена), форму, розміри, консистенцію (щільна, помірно щільна, мажуча), краї (гострі, тупі), структуру пульпи (чи виражена зернистість), ступінь кровонаповнення (значний, помірний), вказує на інтенсивність зіскрібка (незначний, значний).

Приклад: “Селезінка займає природне топографічне положення - на межі залозистої і м'язової частин шлунка. Вона кулясто-овальної форми, темночервоного кольору, із заокругленими краями. Консистенція - м'яка, кровонаповненість - помірна, капсула блискуча та гладенька. На розрізі селезінки реєструється природний рисунок поверхні, зіскрібок дуже малий”.

Описуючи шлунок птиці, експерт зазначає анатомічне положення його частин (анатомічно правильне чи зміщене), розміри, форму, товщину стінки (незмінена, потовщина, потоншена), прохідність кардіального і пілоричного отворів (вільно прохідні, звужені, закупорені), описує вміст шлунка та стан слизової оболонки (колір, наявність слизу, рельєф, висоту складок, стан кутикули), виявлені патологічні зміни.

Приклад: “Шлунок складається із залозистої і м'язової частин. Залозиста частина шлунка локалізується між частками печінки. Стінка його потовщена. Просвіт в ділянці переходу м'язової частини у залозисту звужується. Залозиста частина шлунка веретено- подібна. Слизова оболонка вкрита невеликою кількістю слизу. На іiі поверхні, яка має звичний рельєф, помітні характерні підвищення отворів травних залоз. Патологічних змін в залозистій частині шлунка не виявлено, його прохідність не порушена. М'язова частина шлунка добре розвинута, не збільшена, дископодібної форми 3 щілиноподібною порожниною. Має товсту стінку. В ній дуже добре розвинута м'язова оболонка, яка має сухожилкові утворення, що чітко помітні. Слизова оболонка складчаста і вкрита кутикулою жовтуватого кольору. Вона прозора, щільна і легко відділяється від нижчерозташованих шарів слизової оболонки. Жодних крововиливів, патологічних змін на кутикулі, слизовій оболонці шлунка не виявлено. Вміст шлунка коричнево-зеленого кольору, вологий, складається з гравію і зерняток”.

Описуючи кишечник птиці, експерт констатує анатомічне положення тонкої та товстої кишок (анатомічно правильне, зміщене), описує товщину стінки (потовщена, нормальна, потоншена, розтягнена), прохідність (вільно прохідний, закупорений), вміст, наявність гельмінтів, виявлені патологічні стани.

Приклад: “Тонка кишка (дванадцятипала, порожня і клубова кишки) підвішені на довгій, прозорій, цілісній брижі. Стінка дванадцятипалої кишки з боку серозної оболонки сіро-жовтого кольору, а очеревини червоно-рожева, забруднена кров’ю. В хімусі гельмінти відсутні. Його прохідність не порушена. Тонка кишка 3 характерним вмістом. Слизова оболонка кишки без крововиливів, природного блідо-рожевосірого кольору, помірно вкрита слизом, дещо складчаста".

Приклад: “Товста кишка (сліпі і пряма кишки та клоака) займають природне анатомічне положення. Сліпі кишки мають тоненьку стінку, гладеньку, блідорожевого кольору слизову оболонку, вкриту тягучим слизом. В сліпих кишках реєструються напівсформовані калові маси".

Приклад: “Пряма кишка - природної форми, трубкоподібна. Злегка тягучий слиз виявлено на іiі слизовій оболонці. Незначна кількість напіврідких калових мас сіро-коричневого кольору реєструються в просвіті прямої кишки. На серозній оболонці кишечнику реєструються крововиливи”.

Приклад: "Клоака природної видовженоворонкоподібної форми, закрита. Навколо клоаки пір'я чисте. В iï порожнині вміст відсутній. Слизова оболонка формує поздовжні й поперечні складки, має природний колір та вкрита слизом. Клоакальна сумка добре розвинута, округлої форми, сірого кольору, в розмірах не збільшена. Вона є дорсальним кишенеподібним випином проктодеума. Ії слизова оболонка складчаста, патологічні зміни відсутні. Всередині клоакальна сумка вільна від вмісту”.

Описуючи у висновку підшлункову залозу птиці, експерт зазначає іï положення (анатомічно правильне чи зміщене), розміри (збільшена, не збільшена), форму (плоска і видовжена), колір (бліда, рожева, жовтувата, почервоніла), структуру на розрізі (вираженість часточкової будови), консистенцію (природня, в'яла, ущільнена), наявність патологічних змін. 
Приклад: “Підилункова залоза займає природне топографічне положення: локалізується в брижі дванадцятипалої кишки та чітко підвищується над нею. Вона видовженої форми, світло-рожевого кольору, м'якої консистенції, складається із верхньої і нижньої часток".

Описуючи нирки птиці, експерт вказує на їхні розміри (збільшена, не збільшена), форму, колір (темнокоричневий, червоний, блідий, жовтуватий), наявність патології.

Приклад: “Нирки займають в грудо-черевній порожнині природне топографічне положення: частково розташовуються в заглибинах клубової та попереково-крижової кісток. Каудально вони сягають прямої кишки, краніально - легень. Нирки оточені повітроносними мішками, які утворюють повітряний прошарок, що замінює відсутню жирову капсулу. Їхній розмір не збільшений. Вони мають передню, середню і задню частки, що вкриті фіброзною капсулою і серозною оболонкою. Колір - буро-червоний, консистенція - пружна, гладенька, помірної кровонаповненості, без крововиливів. На розрізі нирки мають характерний рисунок, кіркова i мозкова зони не чіткі. Ниркова миска відсутня".

Описуючи у висновку сечоводи птиці, експерт зазначає довжину, форму та їхню прохідність.

Приклад: “Сечоводи. В ділянці середньої частки за межі нирки виходять сечоводи (лівий і правий). Проходячи по дорсальній стінці порожнини тіла вони відкриваються в уродеум, цілісні, їхня прохідність не порушена".

Описуючи яєчник птиці, експерт констатує його положення (анатомічно правильне чи зміщений), форму (в нормі - гроноподібна), величину (збільшений чи ні), колір, консистенцію; описує яйцепроводи (товщину стінки, колір серозної та слизової оболонок, вміст тощо).

Приклад: “Яєчник. Біля краніального краю нирок розташовується гроноподібний яєчник. Яйцепроводи природної трубкоподібної форми, світло-рожевого кольору, стінка тонка, анатомічно цілісна".

Крім цього, в дослідницькій частині висновку експерта під час дослідження трупа птиці описують стан складових опорно-рухового апарату, зокрема скелетних м'язів: ступінь розвитку, колір (червоний, блідочервоний), консистенцію (пружні, в’ялі); кісток скелета (форма, консистенція, анатомічна цілісність), зв'язок (форма, колір, консистенція, цілісність), суглобів (конфігурація, рухомість, стан синовіальної оболонки і синовії (колір, прозорість, в'язкість), оточуючих їх тканин).

Приклад: “Скелетні м’язи - пружної консистенції, блідо-рожевого кольору. Усі інші скелетні м'язи дещо більш інтенсивно-рожевого кольору, злегка вологі. Слабко розвинута міжм'язова сполучна тканина, в м'язовій тканині трупа журавля розподілена рівномірно і утворює тоненькі фасції. Міжм'язові жирові відкладення відсутні. Під час розрізу скелетних м'язів реєструється їхня помірна вологість, розвинуті. М'язові сухожилки кінцівок добре розвинуті, твердої консистенції, довгі та міцні. Скелет без деформацій.
Кістки правильної анатомічної конфігурації, тверді та цілі. Мають блискуче окістя та м'який кіль, який легко згинається. Грудна клітка округлої форми. Суглоби природних розмірів і конфігурації. Суглобові поверхні кісток блискучі та вологі. Капсула суглобів і оточуючі тканини анатомічно цілі, без ушкоджень".

Окреме місце в розділі висновку експерта "Внутрішне дослідження трупа" відводиться описанню головного мозку і його оболонок. При цьому вказують на стан оболонок мозку (анатомічна цілісність, колір, кровонаповнення іiі судин, стан зрощення 3 кістками черепа, вологість, наявність сторонніх предметів), стан речовини головного і спинного мозку (анатомічна цілісність, стан кровонаповнення іiі судин, стан звивин і борозен, консистенція речовини мозку, запах від нього).

Приклад: “Тверда мозкова оболонка головного мозку сірувато-пергаментного забарвлення, 3 кістками черепа щільно зрощена, волога, мало кровонаповнена. Головний мозок. Тканина головного мозку в'яла, волога".

У кінці розділу "Внутрішнє дослідження трупа" описують всі ушкодження чи патології, виявлені під час внутрішнього дослідження трупа. Порядок розташування виявлених патолого-анатомічних змін залежить від ступеня їх можливого впливу на розвиток стану, несумісного 3 життям (основне/конкуруючі/поєднані захворювання, ускладнення, фонові захворювання, супутні захворювання).

Приклад: “ВИЯВЛЕНІ ПАТОЛОГІЧНІ СТАНИ ТА ПРОЦЕСИ: анемія внутрішніх органів, дистрофія печінки, серця, крововилив в грудочеревну порожнину тіла, крапкові крововиливи на міокарді", або “ВИЯВЛЕНІ УШКОДЖЕННЯ: ушкодження швидкісним висококінетичним тупим предметом в задній частині тулуба; багатофрагментарний розрив нирок; кровотеча в грудочеревну порожнину тіла; розрив лівої легені; уламковий перелом лівої плечової кістки і лівого плечового суглоба; ушкодження швидкісним висококінетичним тупим предметом стінки грудочеревної порожнини зліва; розрив каудальної порожнистої вени; розрив судин легень".

Описуючи в дослідницькій частині висновку експерта стан будь-якого органа чи тканин трупа птиці, доцільно робити посилання в дужках на відповідне фото, розміщене у фототаблиці, як на підтверджуючий факт, наприклад: “Розташування органів грудочеревної порожнини анатомічно правильне (фото № х). У черевній порожнині міститься значна кількість рідини темно-червоного кольору (до $100 \mathrm{~cm}^{3}$ ) (фото № $\mathrm{x})$ ".

У зазначених випадках фототаблиці мають зберігатись у наглядових експертних провадженнях i на вимогу органу (особи), який (яка) призначив(ла) експертизу або залучив експерта, можуть надаватись їм для ознайомлення.

В розділ висновку експерта В. “Додаткові досліджсення" експерт фіксує результати досліджень, виконаних із застосуванням спеціальних приладів (мікроскопа, спектроскопа, люмінесцентного освітлювача, хроматографа тощо) або лабораторних досліджень 
вилученого із трупа біологічного матеріалу (шматочків органів, біологічних рідин тощо) із застосуванням різних методів дослідження: судово-токсикологічних, судово-гістологічних, судово-імунологічних, судовохімічних, мікробіологічних, паразитологічних, криміналістичних тощо із зазначенням номера i дати ї складання.

Приклад: "Результати рентгенологічного дослідження. Дослідження рентгензнімків проводили за допомогою негатоскопу. Рентгензнімок № 1 (лебідь № 1): в нижній третині лівої плечової кістки реєструється рентген-негативне поле діаметром 5 мм, позначене на рентген-плівці цифрою “4”. Рентгензнімок № 2 (лебідь № 1): рентген-негативні поля діаметром 5 мм реєструються в ділянці тазу (позначене на рентген-плівці цифрою “1”), грудної клітки (позначені на рентген-плівці цифрами “2, 3”), нижньої третини плечової кістки (позначене на рентген-плівці цифрою “5”). Рентгензнімок № 3 (лебідь № 2): ренгеннегативні поля діаметром 5 мм реєструються на рентген-плівці: в ділянці лівого плеча (у верхній третині позначено "8" i “7”; а також в середній третині - позначено цифрою “5”), а також в ділянці верхньої третини лівого передпліччя (позначене цифрою “5”)” або “За результатами проведеного дослідження зерна зі шлунка трупа птиці встановлено, що у складі об'єкта, що досліджувався, присутні сліди органічної речовини (зазначається ї̈ назва)".

У випадках вилучення органів і тканин для експертних, наукових або навчальних цілей вказують на проведене втручання і зазначають, що саме вилучене, кому і в який заклад передане.

Після аналізу всіх результатів додаткових досліджень експерт формує підрозділ $\boldsymbol{\Gamma}$. Перелік усіх виявлених під час судово-ветеринарного розтину трупа птиці патологічних змін (станів і процесів), складений у певному порядку та виражений у нозоморфологічних термінах, передбачених загальноприйнятими класифікаціями і номенклатурами хвороб, що відображають причину, патогенез, структурні ознаки й функціональні прояви хвороби чи травми, сформульований судово-ветеринарним експертом на основі даних анамнезу, результатів судововетеринарного розтину і лабораторних досліджень являє собою судово-ветеринарний діагноз.

Формулювання судово-ветеринарного діагнозу хвороби чи ушкодження є відповідальним та складним завданням практичної діяльності судововетеринарного експерта, адже сприяє адекватному, послідовному й обгрунтованому складанню висновка експерта. Він має бути побудований точно, повно, чітко, коротко, логічно, без будь-яких пояснень і обгрунтувань. Ушкодження, патологічні процеси та стани, однорідні за нозо-морфологічним принципом, що виявлені судово-ветеринарним експертом під час розтину трупа птиці, об’єднують.

Загальноприйнятою формою діагнозу є тричленна його структура, яка передбачає послідовний виклад нозологічних форм: основної хвороби (ушкодження), смертельного ускладнення, супутніх знахідок і патологічного фону. Кожна позиція діагнозу має відпові- дати й виходити з дослідницької частини висновку експерта. Посмертні зміни в судово-ветеринарному діагнозі не наводяться.

Судово-ветеринарний діагноз спростовує, підтверджує, уточнює чи розширює клінічний діагноз (у випадку смерті птиці під час лікування). Якщо, крім судово-ветеринарного розтину трупа птиці, були проведені додаткові дослідження, наприклад лабораторні, то їхні результати викладають у висновку експерта перед підрозділом “Судово-ветеринарний діагноз”.

Судово-ветеринарний діагноз будують за нозологічним та патогенетичним принципами із відтворенням послідовності розвитку виявлених змін. Найважливішими є його частини - основна хвороба (ушкодження), її смертельне ускладнення, супутні й фонові захворювання чи ушкодження.

Приклад: “Судово-ветеринарний діагноз: отруєння (назва речовини); застійна гіперемія та набряк легенів; дистрофія печінки, серця; крововилив у підшкірну клітковину нижньої стінки грудо-черевної порожнини та грудо-черевну порожнину тіла; крапкові крововиливи в міокарді".

Якщо судово-ветеринарний експерт не може довести і пояснити причину смерті птиці, то в такому випадку він заявляе про неможливість встановити причину смерті та вказує - 3 якої причини, наприклад, у зв'язку з вираженими ознаками гниття трупа, у зв'язку зі скелетуванням трупа тощо.

Приклад: "У трупі білого лебедя, наданого для судово-ветеринарного дослідження, будь-яких тілесних ушкоджень не виявлено, проте виражені явища гниття і скелетування, а тому визначити давність утворення тілесних ушкоджень не виявлясться за можливе".

Узагальнення та оцінку результатів окремих досліджень, які є підставою для формулювання висновків, експерт викладає у синтезуючій частині висновку експерта. Survey on some hormonal residues in chicken meat, liver and kidneys.локальний статус - ушкоджену ділянку тіла чи органи (Status localis).

Цей підрозділ висновку експерта доцільно розпочинати такою фразою: “Дослідивши матеріали кримінального провадження, внесеного до СРДР

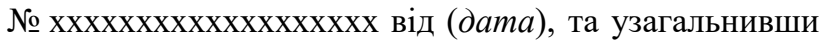
i надавши експертну оцінку результатам судововетеринарного розтину (вид птиці), згідно з постановою слідчого від (дата) судово-ветеринарний експерт констатує таке".

Далі викладають узагальнені дані, в логічній послідовності, отримані з результатів дослідження, обгрунтовуючи їх, проте вони мають бути максимально наближені до відповідей на питання у висновках.

Записи ведуть державною мовою, зрозумілими виразами, з мінімальною кількістю спеціальних ветеринарних термінів. Якщо уникнути цих термінів неможливо, їх зміст пояснюють.

Третьою частиною висновку експерта $є$ "Висновки”. Цю заключну частину висновку експерта розпочинають такою фразою: "Ha підставі судововетеринарної експертизи трупа (вид птиці), матеріалів кримінального провадження № 
Xxxxxxxxxxxxxxx від (дата), у відповідь на питання, поставлені в постанові слідчого від (дата), експерт дійшов таких висновків".

На кожне $з$ поставлених питань має бути дана відповідь по суті або вказано, з яких причин неможливо його вирішити.

- Приклад: “До якого виду належить труп лебедя?

- Труп лебедя, судово-ветеринарне дослідження якого проведене, належить до виду: “лебідь білий”, родини гусакоподібних, належать до класу птиці, типу хордових. Ця тварина належить до хребетних, має головний $i$ спинний мозок, кровоносну $i$ нервову системи", або:

- "Яка причина смерті птииі, наданої для дослідження?

- Причиною смерті лебедя білого № 1 стала “значна крововтрата внаслідок масивної кровотечі", або:

- “Встановити давність виникнення ушкоджень, виявлених в трупі журавля сірого, не уявляється за можливе, оскільки труп перебуває в стані вираженого трупного гниття та має значні дефекти органів за типом тканина-мінус".

- "В трупах птиці № 1, 2 отрути не виявлено (із можливого переліку, наведеного у висновках фахівців з питань токсикології № хххх та № хxх від (дата)), тому і встановити причинно-наслідковий зв'язок між можливим отруєнням і смертю птиці не уявлясться за можливе”.

Відповідно до n. 4.14 Інструкції висновки мають бути сформульовані за результатами дослідження, як відповіді на поставлені питання в послідовності, зазначеній у вступній частині висновку експерта або необхідно зазначити причини, через які неможливо їх вирішити, а також надати відповіді на питання, які вирішувались експертом в порядку самоініціативи.

Нумерація відповідей у заключних висновках (підсумках) повинна відповідати нумерації питань, зазначених у вступній частині висновку експерта, а також питанням, викладеним у процесуальному документі про призначення судово-ветеринарної експертизи.

Заключні висновки (підсумки) у висновку експерта мають бути сформульовані стисло, чітко, конкретно, виразно, без повторів, зрозуміло всім учасникам процесу, повно, мотивовано, на основі фактичних даних, без фраз і мовних зворотів, що передбачають різне їх тлумачення, в категоричній i, як виняток, у ймовірній формах. У разі уживання експертом спеціальних ветеринарних термінів їх пояснюють, щоб вони були зрозумілими усім учасникам процесу, які будуть знайомитись із висновком судово-ветеринарного експерта.

У висновках судово-ветеринарний експерт констатує фактичні дані або їхню відсутність, спираючись виключно на ті фактичні дані, які випливають 3 результатів об'єктивних досліджень, відображених у дослідницькій частині висновку, а також показати причинно-наслідкові зв'язки між ушкодженням і шкодою, заподіяною здоров'ю чи життю птиці.
Схема укладання висновків експерта за результатами проведеної судово-ветеринарної експертизи трупа птиці залежить від характеру та послідовності викладення питань, поставлених на його вирішення.

Висновки у заключній частині висновку експерта підписує експерт чи експерти (у разі проведення комісійної чи комплексної судово-ветеринарної експертизи) із зазначенням їх посади, наукового ступеня, вченого звання, а їхні підписи засвідчуються відбитком печатки експертної установи. Крім того, підписи експертів і відбиток печатки ставлять на кожній сторінці тексту заключних висновків, відповідно до n. 4.15 Інструкції.

Фототаблиці, що додаються до висновку судового експерта, розміщуються після “Висновків”, підписуються експертом (експертами), а його підпис засвідчуються відбитком печатки експертної установи. Якщо експерт працює на професійній основі самостійно та не $є$ працівником державної експертної установи, то він засвідчує наданий ним висновок своїм підписом і печаткою із зазначенням реєстраційного номера облікової картки платника податків (ідентифікаційного номера).

Висновок експерта або експертів (у разі проведення комісійної чи комплексної судово-ветеринарної експертизи) оформлюється на бланку експертної установи і підписується судово-ветеринарним експертом або експертами, який (які) проводив(ли) дослідження.

Якщо судово-ветеринарний експерт не є працівником державної спеціалізованої експертної установи і працює на професійній основі самостійно, він засвідчує наданий ним висновок своїм підписом і печаткою iз обов'язковим зазначенням реєстраційного номера облікової картки платника податків (ідентифікаційного номера) або серії та номера паспорта (для фізичних осіб, які через свої релігійні переконання в установленому порядку відмовилися від прийняття реєстраційного номера облікової картки платника податків), що узгоджується із $n .4 .15$ Інструкції.

Відповідно до n. 4.16 Інструкції, під час проведення комісійної або комплексної експертизи висновок експерта складається за загальними правилами, викладеними в Інструкції, з урахуванням таких особливостей:

- у вступній частині додатково зазначають дані про голову комісії експертів та відомості про експертизи, результати яких задані органом або уповноваженою особою, яка призначила судово-ветеринарну експертизу чи залучила експерта, як вихідні дані;

- дослідження, які проводились окремими експертами, описують у відповідних розділах дослідницької частини, що підписуються цими експертами із зазначенням їхніх прізвищ та ініціалів;

- узагальнення та оцінка результатів досліджень фіксуються у синтезуючому розділі дослідницької частини висновку експертів й підписуються цими експертами із зазначенням їхніх прізвищ та ініціалів. 
Приклад:

ФОТОТАБЛИЦЯ

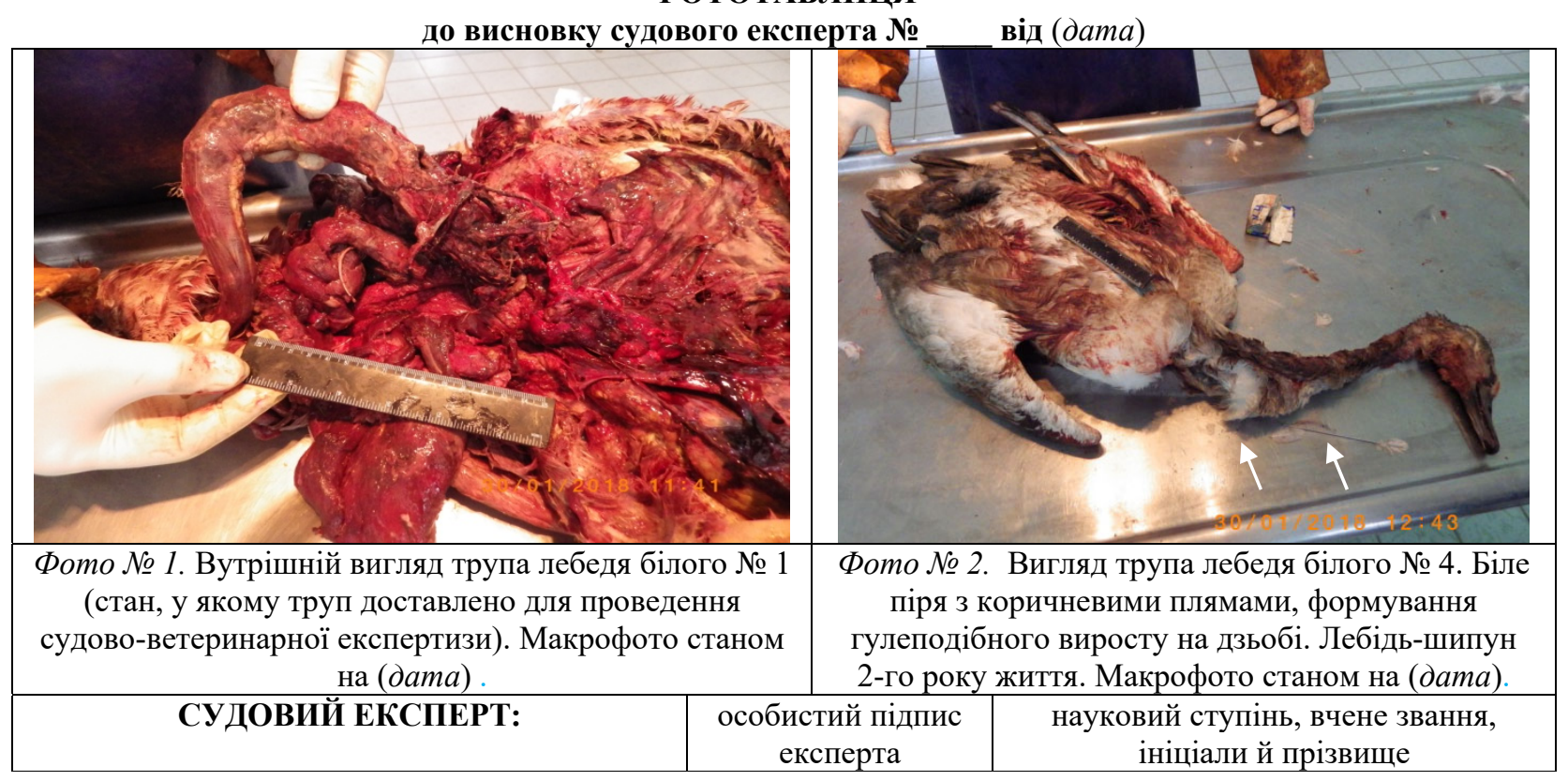

Якщо $з$ одних питань, поставлених в документі про проведення судово-ветеринарної експертизи експерт може дати відповідь, а 3 інших є підстави для повідомлення про неможливість надання висновку, складається один документ - висновок експерта. У цьому випадку судово-ветеринарний експерт зазначає, що він попереджений (обізнаний) про кримінальну відповідальність за статтями 384, 385 Кримінального кодексу України.

Таким чином, запропонований спосіб проведення судово-ветеринарної експертизи з укладанням висновку експерта за результатами судово-ветеринарної експертизи трупа птиці дозволяс оптимізувати роботу судово-ветеринарного експерта на етапі формулювання та укладання висновку. Послідовність викладу результатів судово-ветеринарної експертизи трупа птиці визначається судово-ветеринарним експертом, враховуючи особливості обставин справи, стану дослідженої птиці і змісту питань, поставлених в документі про призначення експертизи.

\section{Висновки}

1. Послідовність викладу результатів експертизи трупа птиці з ознаками насильницької смерті, в т. ч. і за жорстокого поводження, визначається судововетеринарним експертом, враховуючи особливості проведення експертизи, стану об'єкта дослідження і питань, поставлених на вирішення експерта уповноваженим органом чи особою, яка призначила судововетеринарну експертизу або залучила експерта, а також зазначають специфічний об'єкт дослідження, в цьому випадку - труп птиц.

2. Особливістю вступної частини висновку експерта $є$ специфічний перелік питань, котрі ставляться на вирішення судово-ветеринарному експерту. Вони пов'язані з віднесенням птиці до хребетних, як цього вимагає диспозиція ст. 299 КК України, або ст. 89
КУПАП України, причини смерті, характеру та ступеня тяжкості тілесних ушкоджень, їх механізму, черговості, давності, прижиттєвості чи посмертності, наявними ознаками каліцтва, ознаками, за якими можна встановити характер та особливості зброї чи інших знарядь, якими спричинені ушкодження, причиннонаслідкового зв'язку між ушкодженнями і настанням смерті птиці; встановленням, чи могли бути спричинені виявлені ушкодження результатом насильницьких дій над птицею та чи спричинили виявлені ушкодження іiі фізичний біль, страждання і мучення перед смертю.

3. Обов'язковими елементами розділу “Дослідження" $\epsilon$ детальний аналіз судово-ветеринарним експертом окремих ветеринарних документів, що містяться у матеріалах справи (виписки з історії хвороби тварини, амбулаторної карти, протоколу огляду місця події, протоколу дослідження патологічного матеріалу тощо), зазначення реєстраційних даних трупа птиці, описання результатів його зовнішнього та внутрішнього дослідження за визначеними нами алгоритмами, результатів додаткових досліджень (бактеріологічних, вірусологічних, гістологічних, токсикологічних тощо), формулювання судововетеринарного діагнозу та формулювання синтезуючої частини висновку експерта.

4. Заключна частина висновку експерта щодо судово-ветеринарної експертизи трупа птиці є відповіддю на питання, сформульовані у вступній частині в категоричній або, як виняток, у ймовірній формі.

5. Особливістю додатків висновку експерта є те, що вони оформляються у вигляді фототаблиць, котрі несуть інформацію про етапи судово-ветеринарного дослідження трупа птиці, доповнюють і підтверджують вербальну частину висновку експерта.

Перспективи подальших досліджень. Подальші дослідження будуть спрямовані на оптимізацію роботи судово-ветеринарного експерта на етапі формулю- 
вання та укладання висновку шляхом автоматизації даних судово-ветеринарного розтину трупів птиці за допомогою інформаційно-експертної системи “Судово-ветеринарна секція”.

\section{Відомості про конфлікт інтересів}

Автори стверджують про відсутність конфлікту інтересів.

\section{References}

Berny, P., \& Gaillet, J. R. (2008). Acute poisoning of Red Kites (Milvus milvus) in France: Data from the SAGIR network. Journal of wildlife diseases, 44(2), 417426. doi: 10.7589/0090-3558-44.2.417.

Botha C. J., Ste, P. A., Olivier A., \& Bekker L. C. (2011). Nicotiana glauca poisoning in ostriches (Struthio camelus). Journal of the south african veterinary association-tydskrif van die suid-afrikaanse veterinere vereniging, 82(2), 116-119.

Cooper, J. E., \& Cooper, M. E. (1991). Legal cases involving birds - the role of the veterinary surgeon. Veterinary record, 129(23), 505-507.

Crespo, R., Subbiah, M., Corsiglia, C., Bickford A., \& Puschner, B. (2008). Bilateral Malacia Associated with Sodium Poisoning in Turkey Poults. Avian diseases, 52(1), 179-182. doi: 10.1637/8025-053107-Case.

Eggert, S., Thali, M., \& Schweitzer, W. (2019). Bird hunting is to go where the birds are: Alleged single lethal firearm shot to a pigeon in a suburban region. Journal of forensic radiology and imaging, 19, 100339. doi: 10.1016/j.jofri.2019.100339.

Forbes, N. A. (1998). Clinical examination of the Avian forensic case. Seminars in avian and exotic pet medicine, 7(4), 193-200. doi: 10.1016/S1055-937X(98)80064-9.

Guitart, R., Sachana, M., Caloni, F., Croubels, S., Vandenbroucke, V., \& Berny, P. (2010). Animal poisoning in Europe. Part 3: Wildlife. Veterinary journal, 183(3), 260-265. doi: 10.1016/j.tvj1.2009.03.033.

Hernandez-Moreno, D., de la Casa-Resino, I., LopezBeceiro, A., Fidalgo, L. E., Soler, F., \& Perez-Lopez, M. (2013). Secondary poisoning of non-target animals in an Ornithological Zoo in Galicia (NW Spain) with anticoagulant rodenticides: a case report. Veterinarni medicina, 58(10), 553-559. doi: 10.17221/7087-VETMED.

Instruktsiia pro pryznachennia i provedennia sudovykh ekspertyz (Nakaz Ministerstva yustytsii Ukrainy vid 08.10.1998 r. № 53/5 (u redaktsii nakazu Ministerstva yustytsii Ukrainy vid 26.12.2012 № 1950/5) (in Ukrainian).

Karris, G., Martinis, A., Kabassi, K., Dalakiari, A., \& Korbetis, M. (2020). Changing social awareness of the illegal killing of migratory birds in the Ionian Islands, western Greece. Journal of biological education, 54(2), 162-175. doi: 10.1080/00219266.2018.1554597.

Kupper, J., Baurngartner, M., Bacciarini, L. N., Hoop, R., Kupferschmidt, H., \& Naegeli, H. (2007). Carbofuran poisoning in mallard ducks. Schweizer archiv fur tierheilkunde, 149(11), 517-520. doi: 10.1024/00367281.149 .11 .517
Millins, C., Howie, F., Everitt, C., Shand, M., \& Lamm, C. (2014). Analysis of suspected wildlife crimes submitted for forensic examinations in Scotland. Forensic science medicine and pathology, 10(3), 357-362. doi: 10.1007/s12024-014-9568-1.

Morrow, C. J., Noormohammadi, A. H., \& O'Donnell, C. J. (2012). Fatal skull trauma in caged layer chickens associated with a moving feed hopper: diagnosis based on autopsy examination, forensic computed tomography and farm visit. Avian pathology, 41(4), 391-394. doi: 10.1080/03079457.2012.697126.

Naukovo-metodychni rekomendatsii z pytan pidhotovky i pryznachennia sudovykh ekspertyz (Nakaz Ministerstva yustytsii Ukrainy vid 08.10.1998 r. № 53/5 u redaktsii nakazu Ministerstva yustytsii Ukrainy 26.12.2012 № 1950/5. URL: https://zakon.rada.gov.ua/laws/show/ z0705-98\#Text (in Ukrainian).

Pattee, O. H., Carpenter, J. W., Fritts, S. H., Rattner, B. A., Wiemeyer, S. N., Royle J. A., \& Smith, M. R. (2006). Lead poisoning in captive Andean condors (Vultur gryphus). Journal of wildlife diseases, 42(4), 772-779. doi: 10.7589/0090-3558-42.4.772.

Prange, H., Jonas, K., Gottschalk, C., Discher, U., Ribbeck, E., \& Mewes, W. (2000). Peracute mortality in Common Cranes (Grus grus). Berliner und munchener tierarztliche wochenschrift, 113(7-8), 289-294. URL: https://pubmed.ncbi.nlm.nih.gov/10994255.

Raidal, S. R., \& Jaensch, S. M. (2006). Acute poisoning of silver gulls (Larus novaehollandiae) following urea fertilizer spillage. Avian pathology, 35(1), 38-41. doi: 10.1080/03079450500465718.

Russell, R. E., \& Franson, J. C. (2014). Causes of Mortality in Eagles Submitted to The National Wildlife Health Center 1975-2013. Wildlife society bulletin, 38(4), 697-704. doi: 10.1002/wsb.469.

Smart, J., Amar, A., Sim, I. M. W., Etheridge, B., Cameron, D., Christie, G., \& Wilson, J. D. (2010). Illegal killing slows population recovery of a re-introduced raptor of high conservation concern - The red kite Milvus milvus. Biological conservation, 143(5), 1278-1286. doi: 10.1016/j.biocon.2010.03.002.

Tauson, R. (1985). Mortality in laying hens caused by differences in cage design. Acta agriculturae scandinavica, 35(2). 165-174. doi: 10.1080/00015128509435772.

Viner, T. C., Hamlin, B. C., McClure, P. J., \& Yates, B. C. (2016). Integrating the Forensic Sciences in Wildlife Case Investigations: A Case Report of Pentobarbital and Phenytoin Toxicosis in a Bald Eagle (Haliaeetus leucocephalus). Veterinary pathology, 53(5), 1103-1106. doi: 10.1177/0300985816641176.

Wobeser, G. (1996). Forensic (medico-legal) necropsy of wildlife. Journal of wildlife diseases, 32(2), 240-249. doi: 10.7589/0090-3558-32.2.240.

Yatsenko, I. V., \& Derecha, L. M. (2019). Mozhlyvosti sudovo-veterynarnoi ekspertyzy yak novoho vydu sudovykh ekspertyz. Teoriia ta praktyka sudovoi ekspertyzy i kryminalistyky: Zbirnyk naukovykh prats. Kharkiv: "Pravo", 19, 550-567. doi: 10.32353/khrife.1.2019.044 (in Ukrainian).

Yatsenko, I. V., Kliuiev, O. M., Derecha, L. M., SimakovaYefremian, E. B., \& Bulavina, V. S. (2020). 
Zabezpechennia blahopoluchchia domashnikh i silskohospodarskykh tvaryn ta yikh zakhyst vid zhorstokoho povodzhennia $\mathrm{v}$ pravovomu poli Yevropeiskoho Soiuzu. Perspectives of world science and education. Abstracts of the 5th International scientific and practical conference. CPN Publishing Group. Osaka, Japan, 869-881. URL: http://sci-conf.com.ua.

Yatsenko, I. V., Kliuiev, O. M., Simakova-Yefremian, E. B., Derecha, L. M., Smyrnov, H. V., \& Parylovskyi, O. I. (2021). Sudova veterynarna medytsyna: yii mynule, nynishnie i maibutnie. Fundamental and applied research in the modern world. Abstracts of the 8th International scientific and practical conference. BoScience Publisher. Boston, USA. Pp. 1091-1010. URL: https://sci-conf.com.ua/viii-mezhdunarodnayanauchno-prakticheskaya-konferentsiya-fundamentaland-applied-research-in-the-modern-world-17-19marta-2021-goda-boston-ssha-arhiv/ (in Ukrainian).

Yatsenko, I. V., Parylovskyi, O. I., \& Kolomoiets, D. K. (2019). Obhruntuvannia pytan, shcho stavliatsia v ukhvali sudu ta postanovi slidchoho pry pryznachenni sudovo-veterynarnoi ekspertyzy trupa tvaryny $\mathrm{Z}$ oznakamy nasylnytskoi smerti vid zhorstokoho povodzhennia. Veterynariia, tekhnolohii tvarynnytstva ta pryrodokorystuvannia: naukovo-praktychnyi zhurnal, 4, 184-197. doi: 10.31890/vttp.2019.04.34.

Yatsenko, I. V., Zapara, S. I., Zakhariev, A. V. (2018). Suchasnyi stan ta perspektyvy rozvytku sudovoveterynarnoi ekspertyzy v Ukraini. Teoriia ta praktyka sudovoi ekspertyzy i kryminalistyky: Zbirnyk naukovykh prats. Kharkiv: "Pravo", 18, 568-575. doi: 10.32353/khrife.1.2019.044.

Yatsenko, I. V., Zapara, S. I., Zon, G. A., Ivanovskaya, L. B., \& Klochko, A. M. (2020). Animal Rights and Protection against Cruelty in Ukraine. Journal of Environmental Management and Tourism, 11(1), 91-103. doi: 10.14505//jemt.11.1(41).11.

Yatsenko, I., Kliuiev, O., Derecha, L., Simakova-Efremian, E., \& Ostropilets, V. (2020). Ensuring the welfare of wild animals and their protection from abuse in the legal field of the european union and Ukraine. Theoretical foundations of Jurisprudence Collective monograph. International Science Group. Boston: Primedia eLaunch, 179. doi: 10.46299/isg.2020.MONO.LEGAL.II.

Zabudskyi, S. M. (2020). Morfofunktsionalni zminy v orhanizmi sviiskykh kanarok (Serinus canaria domestica) za khronichnoho otruiennia kantaksantynom. - Dysertatsiia na zdobuttia naukovoho stupenia doktora filosofii zi spetsialnosti 211 "Veterynarna medytsyna". Natsionalnyi universytet bioresursiv i pryrodokorystuvannia Ukrainy. Kyiv (in Ukrainian).

Zapara, S. I., Fotina, H. A., Klochko, A. M., Fotina, T. I., \& Yatsenko, I. V. (2019). Revisiting legal understanding of wild life as a sustainable value (the case of Ukraine). Journal of Environmental Management and Tourism, 10(1), 14-21. doi: 10.14505//jemt.v10.1(33).02.

Zon, H. A., \& Ivanovska, L. B. (2014). Sudovo-veterynarna ekspertyza v promyslovomu ptakhivnytstvi. Problemy zooinzhenerii ta veterynarnoi medytsyny, 28(2), 207210 (in Ukrainian). 